Author's Name: Claire Ingram*

Affiliation: Nottingham University Business School, Jubilee Campus, Wollaton Road, Nottingham, NG8 1BB, United Kingdom.

Email Address: Claire.Ingram@nottingham.ac.uk

Author's Name: Dr Robert Caruana

Affiliation: Nottingham University Business School, Jubilee Campus, Wollaton Road, Nottingham, NG8 1BB, United Kingdom.

Email Address: Robert.Caruana@nottingham.ac.uk

Telephone Number: +44 (0) 1158466798

Author's Name: Professor Scott McCabe

Affiliation: Nottingham University Business School, Jubilee Campus, Wollaton Road, Nottingham, NG8 1BB, United Kingdom.

Email Address: $\underline{\text { Scott.McCabe@ nottingham.ac.uk }}$

Telephone Number: +44 (0) 1158466683

* = Corresponding Author

ABSTRACT: Despite a wealth of research on the tourist experience, empirical evidence remains weak due to difficulties in data collection during people's holidays. Tourist experience has thus primarily been analysed from a fixed point, such as prior motivations to travel or retrospective accounts. However, this obscures important information on tourists as they transition through the total experience. This paper presents participative inquiry as a novel methodology for the acquisition of data before, during and after the holiday; facilitating 'prospective', 'active' and 'reflective' triangulation (PART). We provide an empirical example of PARTicipative inquiry in practice, highlighting the benefits and challenges of this approach alongside the (otherwise) hidden insights it reveals into the responsible tourist experience.

Keywords: Tourist experience, participative inquiry, triangulation, responsible tourism 


\section{PARTicipative Inquiry for Tourist Experience}

\section{INTRODUCTION}

The tourist experience continues to beguile and confound researchers in equal measure. It is acknowledged that the experiential dimensions of consumer engagement with brands or tourism destinations is becoming more important to customers, encompassing subjective, emotional and expressive behaviours. Tourists play an active, co-creative role in determining and constituting valuein-use through resource inputs in their experiences in destinations (Prebensen et al, 2013). Hence, firms and destinations have sought to understand goals underpinning tourist experience and to identify ways to incorporate customers' resources into experience design (Fesenmaier \& Zheng, 2017). Showing that the topic is becoming increasingly holistic, Adhikari and Bhattacharya (2016) categorise experience research into four strands: definitional aspects of customer experience, formation of customer experience, consumer psychology in the creation of experience and its consumption, and effects of customer experience.

As our knowledge on the conceptualisation of the dimensions, determinants and consequences of tourist experience develops, so does the need for improved methods and approaches. However, whilst there has been a growth in conceptualisations of the tourism experience, and an increasing recognition that tourist experiences are complex, there has been relatively less progress on the methods used to investigate these new theorisations. In a recent analysis of the literature on tourism experience, Ritchie et al (2011) found that only $3.3 \%$ of studies focus on methodological development in five leading tourism journals between the years 2000 and 2009, the lowest percentage across the five strands of experiential research examined.

The majority of tourism experience research has adopted 'single-point' methods yet, while useful, these can inhibit a fuller understanding of respondents' life worlds. By contrast, several studies have employed multiple methods to actively engage subjects in the research process. For instance, Cederholm (2004: 231) used tourist-generated photography during interviews to 'put the informant in charge of the situation and the story [they] wanted to tell', while Scarles (2010: 906) combined autoethonography and photo-elicitation within interviews to engender 'an embodied connection and understanding between researcher and respondent'. Another body of research has determined aspects of the tourism experience at two or more points in time in order to afford a fuller subjective understanding: examining tourists before and on holiday (e.g. Gyimóthy, 2000); on and after the holiday (e.g. Markwell, 1997), and, more rarely, before, on and after (e.g. Heimtun, 2012). It is this last, rarer 
type that offers the most scope for obtaining deeper insights into lived experiences across the total tourism encounter.

This paper contributes to debates on the theory-methods imbalance by presenting participative inquiry as a means of investigating consumers across the 'prospective', 'active' and 'reflective' phases of tourist experience. More specifically, we develop a comprehensive, collaborative and representative approach for examining the complete tourism experience. Not only does participative inquiry enable emic triangulation of the three key phases of the experience (i.e. Prospective, Active and Reflective Triangulation (PART) ) - hence the term, 'PARTicipative inquiry' - but, more importantly, it is a muchneeded approach for working with participants to explore their experiences in depth. It allows closer examination of 'in the moment' experiences of and by participants themselves as reflective coresearchers, allowing them to contribute their own data relatively free from researcher input. Put simply, it provides three unique yet interrelated datasets and responds to calls for innovative methodologies that 'encourage participant engagement and involvement, individual, subjective expression, and that minimise prior outcome constraints and researcher interference' (Westwood, 2007: 294).

This paper describes the practice and implications of participative inquiry, shows how it maps onto the 'prospective', 'active' and 'reflective' phases of the tourism experience (see Figure 1), and delineates the different types of research questions, study methods and researcher-researched relationships pertinent to each (see Table 1). To facilitate this, we demonstrate how PARTicipative inquiry has been specifically employed in a study into consumers' ethical agency within the responsible tourism experience.

Goodwin and Pender (2005: 303) describe responsible tourism as 'a business and consumer response to some of the major economic, social and environmental issues which affect our world' by 'taking responsibility for the impacts that our actions have'. The Responsible Tourist and Traveller (2005) brochure, advocated by the United Nations World Tourism Organisation, maintains that tourists can 'make a difference' by being open to host cultures and traditions, respecting human rights, preserving natural environments and eco-systems, purchasing local goods, and being attuned to local laws, norms and customs.

Although research has examined the ways in which the tourism industry constructs the responsible experience and choice-sets of consumers (Caruana \& Crane, 2008), a comparatively small segment has explored tourists' understandings of responsible tourism (Miller et al, 2010), what it means to be, and behave as, an 'exceptional' visitor (Stanford, 2008), and how the responsible self is constructed in relation to the industry's 'ideal type' (Caruana et al, 2014: 127). To this end, Tolkach et al (2017: 83) emphasise that little attention has been afforded to 'the role of tourists as agents of ethical judgement and decision making'. This is problematic as, firstly, Weeden (2011: 215) contends that responsible tourists are motivated by a 'range of priorities' and are not immune from engaging in a 'trade-off 
behaviour [with ethics] for reasons of convenience, price and quality'. This suggests that ethical dilemmas may arise prior to and during the holiday which consequently lead to post-trip dissonance for any unresolved, or partly resolved, moral anxieties. Secondly, McKercher et al (2008) find that tourists deploy multiple post-hoc neutralisation techniques to justify their purportedly socially inappropriate behaviours at contested sites. This intimates that responsible tourists are prime subjects for highlighting how actual ('active') behaviour may conform to, or deviate from, initial ('prospective') moral projections in a way which necessitates subsequent ('reflective') rationalisations and resolutions to be ascribed. It is clear that due to the above conceptual issues, responsible tourism is an exemplary context for studying consumers across their complete experience; and that PARTicipative inquiry stands to advance method-theory gaps in (responsible) tourism experience research and broader social science methodology.

\section{PARTICIPATIVE INQUIRY}

Participative inquiry is defined as 'a process of sequential reflection and action, carried out with and by' participants (Cornwall \& Jewkes, 1995: 1667). Participants are actively encouraged to be involved in decision-making and agenda-setting throughout the research process, addressing the typical imbalance of power between the researcher and subject (Cornwall \& Jewkes, 1995) by amplifying their voice (Bowd et al, 2010: 4). Sohng argues that this increased attention to researcher-subject dialogue ultimately results in 'entirely new ways of thinking about issues' (2005: 77). Put simply, researchers and respondents become 'co-producers of knowledge' (Phillips et al, 2013: 1).

Reason (1994) outlines three types of participative inquiry: participatory action research, action inquiry and co-operative inquiry. A key principle of participatory action research is its orientation towards social improvement (McTaggart, 1997). Here researchers and participants collaborate at the group level to identify a research problem, collect data and accrue knowledge that will be of direct benefit or pertinence to the - traditionally disempowered - population studied (Reason, 1994). Action inquiry requires individual participants to self-observe their 'moment to moment' actions so as to expose potential perspective shifts or deviations from intended behaviour(s) (Torbert, 2001: 208). Co-operative inquiry lends itself to the study of the 'human condition' in terms of the cultural modes enabling participation in, as well as self-transformation through, the tourism experience (Heron, 1996).

Alongside different approaches to participative inquiry, there are also a range of stages for undertaking such research. According to Heron (1996), an initial reflective stage (stage 1) requires the researcher and subject to select a line of inquiry and the methods for data collection. The subject then enters the research environment (stage 2) and actively engages in numerous 'mini-cycles of doing and recording' (Heron, 1996: 83). Stage 3 - described by Heron as a 'state of mind [...] at the heart of stage 2' (1996: 
84) - transpires when subjects are fully immersed in their experience and develop novel ways of understanding it (Reason, 1999: 210). Lastly, the researcher and subject reunite for the final stage of reflection (stage 4) and consider how the actual experience played out against the backdrop of the research questions (Heron, 1996; Reason, 1999). Heron (1996) argues that whilst participative inquiry is axiomatically participatory, the degree to which researchers and subjects are involved in each of the four stages may vary.

Participative research is being successfully deployed in consumer research, with Tsybina and Rebiazina (2013) analysing the impact of customer-interconnectedness on portfolio management, and Tretyak and Sloev (2013) refining a model of customer flow to examine the long-term impact of marketing activities on value creation. However, it is yet to gain traction in tourism, in spite of implicit demand for it. Pritchard et al (2011) call for a 'regime change' (p.941) from traditional approaches of investigation in order to 'contribute to tourism's philosophical and ontological development' (p.957). Richards et al (2010:112) contend that 'hopeful tourism' enables 'closer dialogue' with tourists so as to encapsulate the 'individuality' of experiences, and Sedgley et al (2011) demonstrate how the foregrounding of tourist voice produces personalised and socially-inclusive accounts. However, few studies have explicitly adopted participative inquiry as a means of collaborating with research participants as they transition through the tourism experience.

Not all forms of tourist experience may require participative inquiry approaches. However, there are arguments for considering it where, for example, underlying tensions may complicate the smooth apprehension of tourist identities, practices and/or choices by the tourist. Not only is Social Desirability Bias (SDB), for instance, a challenging feature of tourism research design in general (tourism experiences are often significantly performative), but it is particularly heightened in ethics-based studies. Crane (1999: 243) posits that methods requiring 'direct responses from research subjects concerning morality' - such as surveys - are the most prone to SDB. In ethical tourism research, Doran and Larsen (2014) report a 'better-than-average effect' whereby participants express overly positive environmental views when comparing to other 'typical' tourists. Budeanu (2007: 502) echoes this, underlining that 'methods useful for avoiding biased answers [...] are largely missing in tourism'. In this regard methodologies, such as PARTicipative inquiry, which directly embrace (co)reflection on any divergence between intended and actual (un)ethical behaviours, are integral in enabling future tourism researchers to successfully tease out the largely hidden complexities of responsible consumer behaviour.

\subsection{Triangulation}


Triangulation is a fundamental concept in participatory research. The term 'triangulation' has a variety of meanings and has been adopted in various ways by researchers in the social sciences (Smith, 2010). Flick (2004: 178) describes triangulation as the 'observation of the research issue from (at least) two different points'; Beebe (2014: 45) as a strategy to 'test one source against another'; and Denzin and Lincoln (2011:5) as the 'display of multiple, refracted realities simultaneously'. Triangulation has thus predominantly been aligned with the 'crudely realist paradigm', on the assumption that it secures research validity (Seale, 1999: 472). Ultimately, this approach essentially equates triangulation to collecting more data on the same phenomenon, rather than considering different forms of data or observing it from distinct vantage points.

Accordingly, we follow Jick's (1979: 603-604) view of triangulation as a channel for developing 'a more complete, holistic, and contextual portrayal [...] not only to examine the same phenomenon from multiple perspectives but also to enrich our understanding by allowing for new or deeper dimensions to emerge'. In this sense, triangulation becomes a mechanism for augmenting the 'breadth' and 'depth' of research findings in order to construct a more comprehensive, as opposed to 'objective', view of a particular phenomenon (Davies, 2003: 104).

In tourism research, Decrop (1999) outlines how Denzin's (1978) four types of triangulation have been employed, namely: method triangulation, in which several quantitative or qualitative methods are deployed (e.g. Matteucci, 2013); data triangulation, through which an assortment of primary and/or secondary data sources are collected (e.g. MacKay \& Couldwell, 2004); theoretical triangulation, whereby numerous theoretical perspectives are utilised to frame the data (e.g. Kwon \& Vogt, 2010); and investigator triangulation, wherein a number of researchers analyse the dataset (e.g. Conran, 2011).

From this, it is clear that while each of these techniques can be adopted as a means of investigating the multi-dimensionality of the tourism experience, researchers are yet to consider the multiple phases through which a tourist passes as the basis for triangulation. Thus, in taking the 'prospective' (preholiday), 'active' (in-situ) and 'reflective' (post-holiday) phases as three points of triangulation (PART), it is possible to map the dimensions and transitions of tourist experience more effectively. This perspective is sensitive to the position of the subject in the three research phases and is attuned to viewing the tourist as expert in his/her own practices and subjectivities within and across each stage. This engenders a more emic approach to triangulation, whereby the tourist, their experiences and narratives are central and foregrounded. More specifically, rather than view triangulation as a 'search for convergence' (Decrop, 1999: 160), the aim is to uncover the flexible ways in which tourists themselves (re)negotiate their ethical positions within their specific contexts.

\subsection{PARTicipative Inquiry: Triangulated Participative Research}




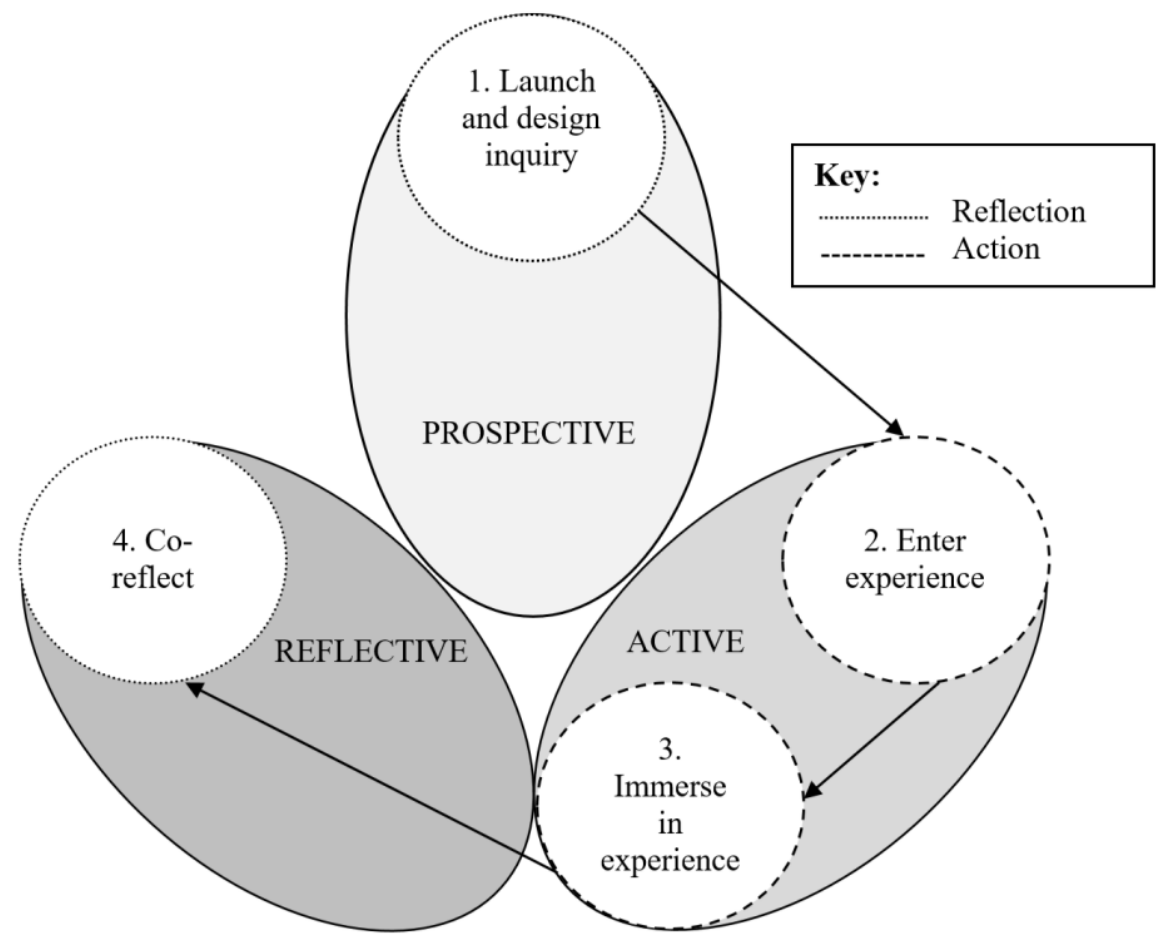

Figure 1 Heron's (1996) four stages of inquiry integrated with three dimensions of 'Prospective', 'Active' and 'Reflective' Triangulation (PART)

Heron's (1996) four stages of action and reflection can be systematically mapped on to the 'prospective', 'active' and 'reflective' phases of triangulation (Figure 1). Stage 4 provides space for tourists to be 'reflective' in ascribing meaning to the ways in which their 'active' participation (actions, behaviours) (stages 2 and 3) was (in)consistent with their choices and motivations projected in the 'prospective' phase (stage 1). It is thus evident that PARTicipative inquiry has the potential to induce novel insights regarding possible deviations between intended and actual behaviours, subsequent tensions, and consequent rationalisations which may otherwise be overlooked. Furthermore, it is also possible that it will provide new insights into how reflections arising from one holiday experience may serve to iteratively (re)shape projections for future experiences (i.e. in subsequent 'prospective' phases). In this sense, PART recognises that tourism experiences can be somewhat circular, as opposed to linear, phenomena. 


\begin{tabular}{|c|c|c|c|}
\hline Position of subject & Pre Holiday & On Holiday & Post Holiday \\
\hline Type/nature of RQ & Projective & Immersive & Retrospective \\
\hline $\begin{array}{l}\text { What can the data tell us } \\
\text { about? }\end{array}$ & $\begin{array}{l}\text { Attitudes, motivations, } \\
\text { decision-making } \\
\text { processes, presumptions }\end{array}$ & $\begin{array}{l}\text { Verbal and material } \\
\text { practices, strategies, } \\
\text { subjectivities, actions, } \\
\text { behaviours and choices }\end{array}$ & $\begin{array}{l}\text { Transformations, } \\
\text { rationalisations, } \\
\text { resolutions, post-hoc } \\
\text { reflections }\end{array}$ \\
\hline $\begin{array}{l}\text { Data types } \\
\text { (and analysis) }\end{array}$ & $\begin{array}{l}\text { Surveys / interviews / } \\
\text { picturing }\end{array}$ & $\begin{array}{l}\text { Diaries / photographs / } \\
\text { ethnography / participant } \\
\text { observation }\end{array}$ & $\begin{array}{l}\text { Art / poetry / active } \\
\text { interviews / tourist } \\
\text { narratives } \\
\text { (Narrative analysis / } \\
\text { discourse analysis) }\end{array}$ \\
\hline $\begin{array}{l}\text { Role of researcher/ed } \\
\text { (Stage of Participative } \\
\text { Inquiry, Heron (1996)) }\end{array}$ & $\begin{array}{l}\text { Launch and design } \\
\text { inquiry, establish pre- } \\
\text { holiday projections } \\
\text { (Stage I) }\end{array}$ & $\begin{array}{l}\text { Subject records } \\
\text { experience (with/without } \\
\text { the researcher) in light of } \\
\text { projections } \\
\text { (Stages II and III) }\end{array}$ & $\begin{array}{l}\text { Collaborate in data } \\
\text { elicitation, meaning } \\
\text { layering and reflections on } \\
\text { action with regards to } \\
\text { earlier views and } \\
\text { interpretations } \\
\text { (Stage IV) }\end{array}$ \\
\hline $\begin{array}{l}\text { Extent of researcher } \\
\text { participation }\end{array}$ & Full & Nil, partial or full & Full \\
\hline $\begin{array}{l}\text { Extent of subject } \\
\text { participation }\end{array}$ & Medium/High & Full & Full \\
\hline $\begin{array}{l}\text { Power-distance between } \\
\text { researcher and subject } \\
\text { (i.e. researcher- } \\
\text { researched relationship) }\end{array}$ & $\begin{array}{l}\text { Medium } \\
\text { (moderate) }\end{array}$ & $\begin{array}{l}\text { Medium-Low } \\
\text { (strengthening) }\end{array}$ & $\begin{array}{l}\text { Low } \\
\text { (stronger) }\end{array}$ \\
\hline Benefits / implications & $\begin{array}{l}\text { Data becomes a } \\
\text { benchmark for 'active' } \\
\text { experience }\end{array}$ & $\begin{array}{l}\text { Draws attention to } \\
\text { (in)congruencies, } \\
\text { tensions and trade-offs } \\
\text { between envisaged and } \\
\text { actual experience }\end{array}$ & $\begin{array}{l}\text { Depicts transition(s) across } \\
\text { the experience and } \\
\text { engenders new } \\
\text { propositions/practical } \\
\text { knowledge for future } \\
\text { holidays }\end{array}$ \\
\hline
\end{tabular}

Table 1 The roles, methods and implications of PARTicipative inquiry

PARTicipative inquiry represents a cogent methodological approach for triangulating the ethical positions of the responsible tourist. This leads to questions of how each phase is receptive to different types of research questions, methods of data collection and analysis, and researcher-researched relationships. Table 1 summarises the nature, methods, degrees of participation, and associated implications which tourism experience researchers may wish to consider (or adopt) at each phase of PARTicipative inquiry.

\section{STUDY METHODS}


To explicate the workings of the three phases, the following section describes how PARTicipative inquiry was employed in an ongoing research project into tourists' ethical agency. The aim of the research was to examine how tourists have the freedom to (re)construct meanings pertaining to 'being' ethical and 'acting' ethically whilst engaging in a responsible mode of tourism. A combination of purposive sampling - i.e. via ethical consumer forums and responsible tourism groups - and snowball sampling led to the recruitment of 16 participants, all of whom self-identified as individuals who participate in a variety of activities and behaviours associated with a responsible mode of tourism (e.g. minimising impacts). The sample size is comparable to that of other recent studies into the tourist experience (e.g. Brown \& Osman, $2017(\mathrm{n}=14)$; Small, $2016(\mathrm{n}=16))$ - particularly those focussing on the niche experience of responsible tourism (e.g. Caruana et al, $2014(\mathrm{n}=16)$; Malone et al, $2014(\mathrm{n}=13)$ ) - and the study was stopped when 'theoretical saturation' had occurred (Silverman, 2015). The sample comprised a balance of male (7) and female (9) participants - aged between 20 and 77 - and a relatively even spread between those engaging in domestic (5), European (4) and international travel (7), leaving no distinct geo-demographic weighting (see Table 2 for sample characteristics).

\begin{tabular}{lllll}
\hline Pseudonym & Age & Occupation & Travelled with & Destination \\
\hline Alex & 20 & Student & University students & Borneo \\
Anne & 54 & Academic support tutor & Family & Devon, UK \\
Barbara & 59 & Personal assistant & Alone & Cambridge, UK \\
Connor & 37 & Dietician & Partner & Peru \\
Edward & 58 & IT/Management consultant & Partner & France \\
Freddie & 54 & Financial advisor & Group of friends & Lanzarote \\
Giovanna & 25 & Charity administrator & Boyfriend & Spain \\
Josh & 32 & Doctor & Wife & Seychelles \\
June & 58 & Retired & Husband and friends & India \\
Lina & 24 & Student & Family & Morocco \\
Mabel & 77 & Semi-retired yoga teacher & Friend & Northumbria, UK \\
Maisie & 44 & Midwife and student & Partner & Blackpool, UK \\
Maria & 32 & Administrator & Partner & Spain \\
Sam & 51 & Local government officer & Wife & New Zealand \\
Sophie & 33 & Physiotherapist and student & Husband & Seychelles \\
William & 24 & Student & Alone & Cairngorms, UK \\
\hline
\end{tabular}

Table 2 Characteristics of sample

\subsection{Data Collection Processes}

Prospective Phase: In the 'prospective' phase, tourists were invited to participate in a 40-45 minute semi-structured, contextual interview. The first purpose of this session was to reiterate the aims of the project and discuss methods of data collection. As the tourists holidayed at different times within a 15month period, it was considered impracticable to co-ordinate full group meetings to co-establish research objectives, hence the researcher had sole control over the broader direction of the research. Participants did, however, have significant input into the research design, and were invited to collect 
data - in addition to (researcher-selected) diaries and photographs - via as many methods as they desired.

The second purpose of the contextual interview was to ascertain tourists' pre-holiday images and projections. Participants were asked to define 'responsible tourism'; describe their identity as a 'responsible tourist'; recall any (non)market ethical or tourism materials that had shaped their understanding of 'responsibility'; discuss their motivations for travel; and relay their planned activities and intended behaviours. This phase evoked significant insights into the elements that they expected from their responsible holiday, alongside those that they hoped to avoid. The data obtained from the contextual interviews served as a discursive template, or benchmark, against which the researcher and/or subject could compare tourists' 'active' (un)ethical practices and subjectivities.

Active phase: The principal aim was for tourists to record their actions, behaviours and choices on holiday. Due to the financial and time commitments associated with tourism, it was not possible for the researcher to actively participate in each holiday experience, hence tourists were the sole researchers in situ. However, the researcher had access to the 'active' data, and was able to uncover any consistent, hidden or deviant patterns of behaviour between projected and actual practices and subjectivities.

Photography was selected as a fitting method for collecting 'active' data on the grounds that taking photographs is a 'deeply rooted, institutionalised part of the tourism experience' (Cederholm, 2004: 226). In conjunction, field diaries were chosen as a means of enabling participants to document their (ir)responsible behaviours - and any associated tensions and anxieties - in 'their own words' (Markwell $\&$ Basche, 1998: 229). For both modes, participants had full autonomy in deciding the content, quantity and frequency of recordings. Out of the 16 participants, 13 took photographs (varying from 5-99) and 15 produced a diary (ranging from bullet points to multiple pages). Half of the participants also gathered data via other methods, including corporate documents (i.e. green codes), magazine articles, leaflets, drawings and poetry. Although the level of input varied, all tourists were able to use their material to prompt discussion, or serve as a reference point, for the 'reflective' interview.

It is noted at this point that a key challenge of PARTicipative inquiry is the participation of tourists in situ. On the one hand, this could mean that tourists (to varying degrees) alter their 'active' behaviour to conform to the aims and objectives discussed in the 'prospective' phase. On the other, it could be that participants are overwhelmed by the demands of the research. Diaries often require 'very strong involvement' (Puczkó, 2010: 67), something which participants may find a 'distracting, disruptive, tiring, and time-consuming process' during a period wherein they are 'busy enjoying themselves' (Shoval \& Isaacson, 2010: 34). Moreover, individuals sometimes prefer not to 'dwell on problems and difficult situations during the holiday itself' (Heimtun \& Jordan, 2011: 277). A related ethical challenge here is that participants may not always feel at ease collecting 'active' data in particular environments. 
It is important, therefore, that the researcher reassure individuals that they need only collect data if they feel comfortable.

Reflective phase: In the 'reflective' phase, 'active' data was used as a prompt to: (1) stimulate discussion on actual actions, behaviours, choices and decisions; (2) (co)reflect on any deviations, trade-offs and tensions; and (3) elicit any subsequent resolutions, rationalisations and transformations. In this regard, the researcher worked with participants to map behaviour across the phases in order to pull together thematic threads across the three datasets.

To do this, the project adopted Holstein and Gubrium's (1995) approach to 'active interviewing'. Together, the researcher and participants reviewed the 'active' data in connection with the 'prospective' data, not only to 'make sense' of the tourism experience, but to further highlight the 'meaningful patterns' that subsequently emerged (Heron, 1996: 87-88). 'Reality' was (co)negotiated in the active interview by the researcher - in response to the participant's reflections - 'shifting' positions in order to examine their 'stocks of knowledge' from alternate perspectives. In this way, the researcher sometimes picked up on linkages that the participant had not previously considered, and/or instances where the participant confirmed or denied the researcher's interpretations. It is noted that while participants had the freedom to give meaning to their experience in the active interview, they were not directly involved in the (later) data analysis process.

With regards to ethics, it is important to note that as certain lines of inquiry may highlight inconsistencies between initial projections and actual behaviours, the researcher had to remain sensitive to the potential (emotional) reactions of participants. Whilst in this study all participants were happy to discuss incongruities, and self-question their ethics, they had been assured that they would remain anonymous and that they could withdraw at any time.

Given the (co)reflective nature, the power-distance between the researcher and the researched was minimal. Nevertheless, while all participants had the freedom to initially steer the direction of the interview, some participants took greater control over the course of the session than others. Hence a challenge for the researcher was to be cognisant that the varying personalities within the sample may necessitate different degrees of probing amongst participants. However, this was lessened through the relationship that had developed over the preceding phases.

\section{FINDINGS}

In this section, some of the key findings into responsible tourists' experience are outlined to facilitate the discussion on the benefits and challenges offered by PARTicipative inquiry. It is important to note 
that the primary purpose of this section is to depict how certain findings arose solely as a result of conducting a PARTicipative inquiry, and not to elicit new empirical insights into consumers' ethical agency per se. To present the data, we draw on four of the most prominent themes to emerge, synthesised over the three phases of data collection, and select illustrative respondents that were typical of these themes. In the same way that Willson et al (2013) focus on the data of one participant, we provide the data of four respondents - Barbara, Sam, Alex and Sophie (see Table 2) - to allow for several voices 'to be heard clearly amongst the clutter of many' (p.158).This enabled us to more easily view/highlight, for example, the (in)consistencies, deviations and reconciliations that run through respondents' transcripts across the imagined, lived and retrospective phases of the responsible tourism experience.

\section{1. 'Walking the Talk'}

A prominent theme to emerge from our data concerned respondents whose experience was one of ethical praxis; an attempt to transform personal ethical reflection into action. Typical of this theme, Barbara views ethical tourism in terms of her self-determining ability to arbitrate over matters of right and wrong. In the main, she asserts a high locus of control over ethical tourism practice by 'walking the talk'. Nevertheless, in striving for non-compromising practices ethically, she faces (emotional) compromises personally.

In the 'prospective' phase, Barbara spoke of her plans to drive to an eco-lodge in Snowdonia (Wales, UK) with her grandchild. She argued that, although nothing obstructs her from being ethical when travelling solo, her locus of control is impeded by other responsibilities, in particular to being a good grandparent, when taking her young grandson. This reinforced her decision to travel by car rather than take a four-year-old on a train:

.... What impedes me is... if I was going on my own, nothing impedes me. If I'm taking [grandson] [...] everything impedes me [laughter]. And that must be for all families, even though families do do it - they will get on the train with two or three children.

After the 'prospective' interview, Barbara was highly reflexive as to whether her projected practice conformed to her ethical ideals. Although she had initially claimed that driving was "not doing anything" (compared to flying), she later self-questioned her car-use to the extent that she opted to holiday without her grandson, so that she could travel by train. She writes in her diary:

After speaking with [researcher], I really wondered about myself, mostly my ethics. I do live an ethical lifestyle but still use the car a lot. I could go by train with [grandson]but the hassle? How strong are my ethics about travelling? [...] I've always wanted to go to Cambridge...not quite Snowdonia...and I could go by train. 
However, trading a holiday with her grandson resulted in feelings of disappointment. The following extract demonstrates the ways in which musings in the 'active' phase stimulate novel projections of ways to travel with her family while still minimising her impact:

Feel disappointed that I didn't find a holiday for [grandson] and I...funnily enough I bought Permaculture mag and there were several places [grandson]and I could have gone to do something eco and not too far away but still a little expensive [...]. Anyway I will definitely look at ways to travel to tread even lighter on this earth....and take [grandson] with me.

When discussing other "feelings of ouch" in the "reflective' phase, Barbara ultimately thought she had taken the easy option by travelling to Cambridge. She states:

An "ouch" usually comes with something that - a realisation on my part that I'm perhaps not living up to something. And I did feel that I didn't live up to it going to Cambridge. I think it felt like a cop out really. But I was restricted by time and everything. But really I thought to myself, "really, you know, you could have gone abroad". "You could have gone on a train, you could have gone through the, you know, the tunnel and gone and pushed yourself to do something".

Barbara felt that she still wasn't "living up to something", and that she could have "pushed" herself to travel abroad by train. This is particularly interesting, given that she also avoided her initial destination, Snowdonia, after questioning whether her car-use jeopardised her ethical ideals.

Barbara's case is an example of how PARTicipative inquiry spotlights hidden compromises that tourists make in their efforts to 'walk the talk'. Had we only conducted a post-hoc interview, we would not have appreciated the role of family ties in impeding her personal ethical agency ('prospective' phase), nor her later resolve to include her family in future ethical travel plans ('active phase'). Equally, we would not have been able to draw subtle links between the reasons she cancelled her trip to Snowdonia and the reasons she was somewhat dissatisfied with Cambridge. Thus, PART allows us to examine the extent projections lead to material changes in behaviour when moving from the 'prospective' to 'active' phase whilst also probing for rationalisations. In particular, her transcripts highlight how tourists' involvement in PARTicipative inquiry facilitates self-reflexivity, and how this results in researcher access to dilemmas at the heart of experiences. Barbara herself alluded to the personal benefits of selfreflection, ending her final interview with the comment: "I'd like to thank you for giving me this opportunity really, just to... I feel quite emotional actually because we've been talking about stuff that's really quite precious eh?".

\section{2. 'Reflexive Inertia'}

In stark contrast to 'walking the talk', other respondents were reflective about ethics but sometimes unwilling to translate this into behaviour. Here the locus of ethical agency is not experienced as being with the individual tourist, but with the holiday product. Sam personifies this position. He is overtly 
aware of the environmental contradictions involved in tourism and how going on an eco-holiday provokes dilemmas and trade-offs. Yet, equally, he is openly candid that he does "not make 'ethically correct' choices while being a tourist as much as [he] hoped", often prioritising exceptional, "once in a lifetime" experiences. Thus, the term 'reflexive inertia' serves to underline the capacity of some tourists to comprehend, in quite sophisticated ways, the ethical implications of their experiences without making corresponding adjustments to their actions.

In the 'prospective' phase, Sam was excited about the prospect of becoming a co-researcher and was enthusiastic to maintain a diary, disclosing that he would enjoy viewing his experience of New Zealand from an ethical perspective:

It will be fun. It'll be good to look at it from that side of things. Because I think I sort of feel somewhere like New Zealand would have quite a good record in that respect. So I'd be interested to test that theory in some ways.

Despite intending not to "go out of [his] way" to collect data, Sam later contemplated the extent to which he was overly aware in the 'active' phase, questioning whether he was considering ethics more than he perhaps would have done:

[My wife] thinks I could be exhibiting the 'Hawthorne Effect' as I am reflecting on ethical issues which I don't think I would have done so (as much) if I had not been a part of [the] study!!

At the same time, Sam recognised that his ethics are likely to be bracketed by his greater desire to participate in particular, novel excursions - such as a helicopter ride - and notes that, more often than not, he doesn't feel "guilty" or "wracked" with the need to compensate. Any ethical responsibility (benefitting a local business) occurs as a secondary outcome of the holiday experience:

I think my decisions are primarily driven by affordability and whether I want to have the experience or not. For example, I did a helicopter ride over and onto the glaciers. Not environmentally sound, unsustainable and contributes little to preserving the environment. However, to me it was a once in a lifetime thing and so I just did it despite the expense too. I may have 'supported' a local business but that wasn't the primary justification for doing it. I must admit that I also didn't feel guilty or wracked with the need to offset my footprint consciously.

So I suppose I do what I want to do on holiday, cost permitting, and then sort of justify it to myself that there is some element of doing those things that is ethical - so it's more retrospectively ethical - rather than prospectively perhaps?

Sam continued to consider his role in the study in the 'reflective' interview. First, he recounted the way in which he experienced the Hawthorne Effect as an associated challenge of PARTicipative inquiry. Second, he displayed a sense of bounded rationality through highlighting how he overcame the challenge, namely by 'stepping back', behaving as normal, and reflecting upon any potential influences: 
The Hawthorne effect stuff was quite interesting, because I did feel at points where I was looking out for things that I wouldn't have looked out for before if I hadn't of done this. But then I sort of stepped back a little bit from that. And we sort of thought "well, no, let's just do what we were going to do. And then reflect on whether that was, you know, whether those choices, or what we saw - or whatever it was - was influencing what we would have done anyway".

Sam was also keen to reflect on his surprise that he had inadvertently referred to his initial projections when collecting his 'active' data. This demonstrates participants' perceived value of mapping projective, immersive and retrospective data to deduce any (un)intended (dis)connections between planned and actual behaviour.

But what I thought was interesting was reading the transcript from my pre-holiday interview. It's funny how I actually mentioned quite a few of the things that we actually then reflected on in the diary that I wrote while I was there.

Like Barbara, Sam's involvement led to highly reflexive thinking at the empirical level, yet also differed, in that he (interrelatedly) became particularly methodologically reflexive, a self-aware instrument of the research design.

\section{3. 'Rhetorical Cognisance'}

Agency can also be represented in terms of a critical awareness about the 'conditions of [their] freedom'; with tourists challenging the discourse of ethical tourism as 'marketing rhetoric'. That is, subjects consider there to be power structures (market/class etc.) that significantly limit the potential ethicality of tourism experiences. Alex's data maintains a very strong and conscious reflectivity about those tourists who are unwittingly seduced by the promise of ecotourism. He highlights the paradoxes of an ethical experience, which to engage in through market mechanisms, means being increasingly disengaged from ecosystems. To take responsibility, Alex believes that one must get dirty, endure discomforts and leave the cosy safety net of the tourist bubble. Alex's narrative is interesting, as whilst he enjoys pointing out that (marketed) ethical tourism is self-illusory, he makes no material alterations to his occasional participation in such contrivances.

In the 'prospective' interview, Alex emphasised his cynicism towards ecotourism. He thought that ecotourism was a marketing niche "aimed at the sort of the crème de la crème", which while not necessarily a bad thing - as "conservation needs money and you may as well kind of loosen up the rhetoric in order to get it" - results in an "ethical wash for something that's not actually that substantial". Travelling to Borneo as part of an ecology fieldtrip, Alex projected that his time spent at a sustainable lodge would be a "woolly" approach to conservation: 
So for example the place we're going in Borneo, there's the research station which we're going to and then there's like the [Name]Lodge, which for a three night stay is like £14,000 or something horrendous like that. And, yeah, I think a lot of the rhetoric for that is that they... it's a very simplified, basic version - "oh, you know, you're supporting this ecosystem" in this kind of woolly way.

In the 'active' phase, Alex lives his contradictions. Unlike Barbara, his sense of self-determination disappears, and he 'finds himself' within the luxury trappings of the ecotourism market. However, he is quick to absolve his behaviour by pointing out that this is not an 'ethical' activity he would normally participate in, while concurrently questioning why others would want this experience. He writes:

Well, I have found myself reclining in dreamful ease on the lounger of a luxury resort [...]. It looks like one of those places that a) is advertised in brochures and b) I would never intentionally visit. Interesting to see the contrast in what people want from an area like Borneo. What's the point of paying thousands of pounds just to sit somewhere warm and quiet?

In the 'reflective' phase, Alex confirmed that his initial projections were realised, albeit "far and away more extreme than [he] thought". Alex draws on discourses of authenticity to compare the lodge's sanitised approach to ecology - such as "a boardwalk in the canopy [...to] get all these beautiful like classic views of the rainforest" - to how he has "seen lots of stuff", specifically by "walk[ing] through the shit on the ground, and like dig[ging] in the mud, and break[ing] open logs, and climb[ing] up trees". This discrepancy between the market and personal approach to 'responsibility' led Alex to view the lodge as a "total gimmick" which imposed "like a documentary idea of a wild place on to the way you visit it".

Overall, Alex's case differs from that of Barbara and Sam, in that it evidences how the scope of participants' projections, actions and reflections can remain relatively constant as they transition through the holiday. In these instances, PARTicipative inquiry is particularly useful in uncovering the otherwise hidden strength of consistency. More specifically, the projected data can act as a discursive barometer (as opposed to template) against which actual attitudes can be evaluated (as opposed to contrasted). This is important because, while the scope of projected attitudes may remain static across the three phases, the intensity of these attitudes may wax or wane.

\section{4. 'Pragmatic Utility'}

In contrast to tourists like Alex, who are highly aware of being trapped in marketing discourse, Sophie considers her ethical agency to be largely contingent upon whether the holiday product allows her to be ethical or not. This manifested in her unrealised desire to eat local, authentic food as opposed to the international buffet provided by the hotel chain. Sophie also, therefore, stands in stark contrast to Barbara, in the sense that she has a low locus of control over the ethicality of her experience; she is not in control of the choice of cuisine available and simply accepts her situation. In the following passages, 
there are two things to note. Firstly, despite her great frustrations about her perceived lack of choice, she provides a 'pragmatic utility' rationalisation as to why she yielded to these restrictions. Secondly, her case stands out as interestingly lopsided across the three datasets, with very little offered in the 'prospective' and 'active' phases compared to the landslide of post-hoc rationalisation we witness in the 'reflective' phase.

When discussing the content of hotels' sustainable codes and policies in the 'prospective' phase, Sophie briefly commented that she would be interested in having more information regarding the sourcing of food. She went on to state:

I'm interested in food and kind of where it comes from, and I think that's part of the enjoyment of going to new places is eating local food and whatever. So, you know, if things are sourced locally and stuff I would... that would definitely be a plus side to me.

In the very last section of her diary, Sophie wrote that she disliked the fact that the food was buffet service, namely on the grounds of waste:

I hate them! And people who overload plates! I don't enjoy it but it also seems very wasteful.

It is interesting to note that Sophie only reported her irritation in her diary, and didn't directly frame her gastronomical experience as a deviation from her projected responsible behaviour (i.e. "eating local food"). It wasn't until the 'reflective' interview that Sophie contrasted her enjoyment of local produce and local dining with her aversion to the buffet fare of "eating pizza with a curry, or whatever". Here, she was keen to emphasise that the buffet was "the only option":

I love eating out, and I love sort of eating local food and all that kind of stuff. And that again is quite important to me when I go on holiday. The first place we stayed, we did stay half board. Because actually that was the only option, I don't think we could stay bed and breakfast - I think you had to do half board. And the options really were this sort of huge buffet type sort of restaurant.

The researcher asked Sophie whether "if [she] had have had the choice would [she] have preferred to just do the bed and breakfast, and then eat in the local [vicinity]?". She replied that she "would definitely have preferred" this, and, "rather annoyingly, there was an absolutely brilliant local sort of restaurant just across the beach". Of this restaurant, Sophie reflected:

And it was really frustrating, because I thought "actually, we'd have probably gone for dinner there every single night" if we could have done. But, you feel like you've paid to be half board, so it feels like... you know, if you've paid for one thing, going and spending money elsewhere doesn't feel right.

The researcher probed further to clarify this 'feeling':

Interviewer: The money tension again? 
Sophie: $\quad$ Money tension again, yeah absolutely. That, you know, if you've paid for one thing, going and spending money elsewhere doesn't feel right.

In this example, Sophie gave a 'value for money' logic, suggesting that her decision to commit to something she "really [didn't] want to do" was more to do with being an efficient, value-maximising consumer, even if it was at the expense of sacrificing one of her initial enjoyments. She would have liked to have 'walked the talk', like Barbara, however the constraints of her tourism product imposed a set of parameters around what she was actually willing to achieve.

In summary, this case highlights the value of PARTicipative inquiry on two counts. Firstly, it underlines how the 'reflective' phase provides participants (and researchers) the space to elaborate on 'active' data and, in turn, relate to 'prospective' data (especially helpful when this is comparatively thin). Had Sophie not been given the space to rationalise her behaviour post-holiday, the researcher would only have known that she "absolutely hates" food wastage (i.e. an ethical issue), and thereby remained oblivious to the financial tensions that prevented her from overcoming this issue as well as the explicit personal sacrifice she made by not eating locally. Secondly, it provides an example of the ways in which the researcher and participant can conjointly negotiate layers of meaning. For instance, while Sophie professed that she didn't "think [they] could stay bed and breakfast" and that they "had to do half board", it was: (1) the probing question of the researcher that explicitly led to her statement that she would have wanted "to get out and sort of try local sort of stuff as well", and (2) a clarification question that served to unequivocally reveal the (financial) reason/tension for eating within the confines of the hotel.

\section{DISCUSSION AND CONCLUSION}

PARTicipative inquiry offers an effective platform for collaborating with participants at the 'prospective', 'active' and 'reflective' phases and yields rich triangulated data that adds significant value to future research into the tourist experience.

\begin{tabular}{ll}
\hline Dimension & Suggested Guidelines \\
\hline Prospective & Relay/discuss/determine research aims and objectives \\
& Ascertain tourists' pre-holiday projections (i.e. attitudes, motivations etc.) \\
(Co)determine data collection methods and/or content for 'active' phase & Tourist (and possibly researcher) enters the holiday experience \\
Active & Tourist (and possibly researcher) collects experiential data via agreed methods \\
& Tourist compares 'active' and 'prospective' experience to highlight (in)congruencies \\
Reflective & Researcher and tourist reconvene post-holiday \\
& Researcher and subject use 'active' data as prompts to (co)reflect \\
& Researcher and subject assign meaning to actions in the 'active' phase relative to the \\
& initial presumptions of the 'prospective' phase \\
\hline
\end{tabular}


Researcher and subject discuss (potential) new projections for future experiences

Table 3 Suggested guidelines for conducting PARTicipative inquiry

In following the suggested guidelines for conducting a PARTicipative inquiry (Table 3), it is clear that there are several implications for future tourism research. Tourists will always be afforded greater opportunities to reflexively interpret their own actions, behaviours and choices than in more traditional modes of qualitative research. This changed role of the participant not only engenders closer interpretations of the data, but further increases the researcher's layers of understanding of the tourist experience. These implications have additional positive ramifications for the trustworthiness (and quality) of research. Drawing on Guba's (1981) qualitative criteria, the credibility of findings should be enriched given the (co)constructed nature of findings and inferences. For instance, the full participation of the subject in the 'reflective' phase serves as a form of 'member checking', since the researcher and researched collaborate in the data elicitation process. This also impacts on the confirmability of conclusions, as power imbalances between the two parties are reduced to allow tourists the freedom to (dis)authenticate any believed inaccuracies (e.g. 'confirmability audit').

At the methodological level, PARTicipative inquiry yields considerable benefits through triangulating the distinct yet interrelated phases of the responsible tourism experience. Primarily, there are significant advantages to engaging with the research subject in the particular context in which (s)he is situated at any point in time. It ensures that the nature of the research questions (i.e. projective, immersive, retrospective) are congruent with the types of data the researcher wishes to obtain (i.e. presumptions, practices, post-hoc inferences), and that the methods through which the researcher/participant collects the data (e.g. surveys, field methods, narratives) are appropriate for the position of the subject (i.e. preholiday, on-holiday, post-holiday).

PART further enables an examination of how the phases interact, while taking advantage of unique methodological opportunities in the synthesis of the analysis. For instance, (i) subjects can take a ('prospective') discursive 'template' into the 'active' phase as a reminder of self-envisaged actions and behaviours; (ii) subjects can record any deviations, moral anxieties or dilemmas in their diaries; (iii) researchers and subjects can use the diaries to prompt retrospective accounts and reflections. This not only serves to effectively 'mine' the data, but, more critically, provides new layers of meaning as to how responsible tourism is experienced within and across different times and spaces. More specifically, PARTicipative inquiry provides three unique datasets from which the researcher can both access the (individual) core pre-holiday, on-holiday and post-holiday phases, and (collectively) map the ways in which the responsible tourist transitions through the totality of the experience. 
It is evident from the findings that triangulated participative inquiry is particularly suited to the study of responsible tourism as it teases out the ways in which tourists (un)happily conform to, or deviate from, ostensibly ethical practices and subjectivities. As the excerpts demonstrate, PARTicipative inquiry is instrumental in uncovering otherwise hidden insights into the strength/scope of consistency (e.g. Alex) and inconsistency (e.g. Sam) between projections, actions and retrospections on responsible travel. The analysis shows how deviant actions (based on initial projections) can be rationalised (e.g. Sophie), alongside how conformist actions can serve to completely re-shape motivations for future holiday experiences (e.g. Barbara). The researcher becomes cognisant to how tourists sometimes smooth over certain practices and subjectivities, or indeed reconfigure their ethical stances, as they transition through the responsible tourism experience. We observe how this particularly impacts the more reflexive participants; who, for example, question their ethical positions and ideals (e.g. Barbara) or continue with their desired activities and, if possible, ascribe a post-hoc ethical rationale (e.g. Sam).

PARTicipative inquiry is not without its challenges. Sam, for instance, is extremely methodologically reflexive over whether he exhibited the Hawthorne Effect. Yet, equally, his reflections demonstrate how participants are afforded a significant level of control over defining (and establishing degrees of) their participation, as well as how they are ultimately empowered to determine how to proceed when faced with such challenges (i.e. 'behaving as normal'). A second potential challenge is participants' varying levels of involvement across the three phases. For example, with regards to the specific issue of food, Sophie recorded comparatively little data in the 'prospective' and 'active' phases relative to her indepth post-hoc rationalisation in the 'reflective' phase. This challenge is at least partially overcome in that PARTicipative inquiry enables the researcher and researched to (co)negotiate meaning. The researcher can ask probing and clarification questions - in areas where data may potentially be lacking - to ensure that all areas of the total tourism experience are fully interpreted.

Although participative inquiry is substantially under-developed in the study of tourist experience, it is unsurprising that, in light of greater consumer involvement and engagement as collaborators in experience design (Fesenmaier \& Zheng 2017), subject participation at the methodological level is also beginning to emerge. This paper contributes to the methodological strand of experiential literature by offering guidelines for (Table 3), and the implications of (Table 1), conducting comprehensive and collaborative research via PARTicipative inquiry. We show that PARTicipative inquiry is especially suited to the study of 'value-laden' (Sharpley, 2013: 385) phenomena, such as responsible tourism, wherein tourists expect their experience to involve profound personal, social and/or ecological transformation. By distinguishing the three distinct yet interrelated phases through which individuals transition, future researchers can gain new insights (at each phase) which advance our theoretical and conceptual understanding of tourist experiences more generally and responsible tourism experiences in particular. 
In conclusion, PARTicipative inquiry is ultimately an effective platform for triangulating the 'prospective', 'active' and 'reflective' phases that tourists are positioned in and transition through. Participation facilitates a subject-oriented and context-specific approach, allowing researchers and subjects to (co)examine how tourists reflect on their actual (ir)responsible actions relative to their initial projections and motivations. The unique context of each phase serves to elicit specific types of empirical insights, alongside a particular set of methodological implications for researchers to consider. PARTicipative inquiry can be applied beyond the case of responsible tourism to provide richer and more complete understandings of transitional subjects across the totality of a given experience, or indeed in project-related areas which would benefit from greater collaboration, thus offering great potential for further research across a range of experience contexts.

\section{References}

Adhikari, A. \& Bhattacharya, S. (2016). "Appraisal of Literature on Customer Experience in Tourism Sector: Review and Framework", Current Issues in Tourism, 19(4): 296-321.

Beebe, J. (2014). Rapid Qualitative Inquiry: A Field Guide to Team-Based Assessment (2nd Edition). London: Rowman \& Littlefield.

Bowd, R., Özerdem, A. \& Kassa, D. G. (2010). "A Theoretical and Practical Exposition of 'Participatory' Research Methods", in A. Özerdem and R. Bowd (Eds). Participatory Research Methodologies: Development and Post-Disaster/Conflict Reconstruction, pp.1-18. Surrey: Ashgate Publishing.

Brown, L. \& Osman, H. (2017). "The Female Tourist Experience in Egypt as an Islamic Destination", Annals of Tourism Research, 63: 12-22.

Budeanu, A. (2007). "Sustainable Tourist Behaviour - A Discussion of Opportunities for Change", International Journal of Consumer Studies, 31(5): 499-508.

Caruana, R. \& Crane, A. (2008). "Constructing Consumer Responsibility: Exploring the Role of Corporate Communications", Organization Studies, 29(12): 1495-1519.

Caruana, R., Glozer, S., Crane, A. \& McCabe, S. (2014). “Tourists' Accounts of Responsible Tourism", Annals of Tourism Research, 46: 115-129.

Cederholm, E. A. (2004). "The Use of Photo-Elicitation in Tourism Research - Framing the Backpacker Experience", Scandinavian Journal of Hospitality and Tourism, 4(3): 225-241.

Conran, M. (2011). "They Really Love me! Intimacy in Volunteer Tourism", Annals of Tourism Research, 38(4): 1454-1473.

Cornwall, A. \& Jewkes, R. (1995). "What is Participatory Research?”, Social Science \& Medicine, 41(12): 1667-1676.

Crane, A. (1999). "Are You Ethical? Please Tick Yes or No: On Researching Ethics in Organisations", Journal of Business Ethics, 20(3): 237-248.

Davies, B. (2003). "The Role of Quantitative and Qualitative Research in Industrial Studies of Tourism", International Journal of Tourism Research, 5: 97-111.

Decrop, A. (1999). "Triangulation in Qualitative Tourism Research", Tourism Management, 20 (1): $157-161$.

Denzin, N. K. \& Lincoln, Y. S. (2011). The Sage Handbook of Qualitative Research (4th Edition). Thousand Oaks: Sage.

Doran, R. \& Larsen, S. (2014). "Are We All Environmental Tourists Now? The Role of Biases in Social Comparison Across and Within Tourists, and Their Implications", Journal of Sustainable Tourism, 22(7): 1023-1036. 
Fesenmaier, D. R. \& Zheng, X. (2017). Design Science in Tourism: Foundations of Destination Management. Vienna: Springer.

Flick, U. (2004). "Triangulation in Qualitative Research", in U. Flick, E. von Kardorff and I. Steinke (Eds). A Companion to Qualitative Research, pp. 178-183. London: Sage.

Goodwin, H. \& Pender, L. (2005). "Ethics in Tourism Management", in L. Pender and R. Sharpley (Eds). The Management of Tourism, pp.288-304. London: Sage.

Guba, E. G. (1981). "Criteria for Assessing the Trustworthiness of Naturalistic Inquiries", Educational Communication and Technology, 29 (2): 75-91.

Gyimóthy, S. (2000). "Visitors' Perceptions of Holiday Experiences and Service Providers: An Exploratory Study", Journal of Travel \& Tourism Marketing, 8(2): 57-74.

Heimtun, B. \& Jordan, F. (2011). "'Wish YOU Weren't Here!': Interpersonal Conflicts and the Touristic Experiences of Norwegian and British Women Travelling with Friends", Tourist Studies, 11(3): 271-290.

Heimtun, B. (2012). "The Friend, the Loner and the Independent Traveller: Norwegian Midlife Single Women's Social Identities when on Holiday", Gender, Place \& Culture, 19(1): 83-101.

Heron, J. (1996). Co-operative Inquiry: Research into the Human Condition. London: Sage.

Holstein, J. A. \& Gubrium, J. F. (1995). The Active Interview. Thousand Oaks: Sage.

Jick, T. D. (1979). "Mixing Qualitative and Quantitative Methods: Triangulation in Action", Administrative Science Quarterly, 24(4): 602-611.

Kwon, J. K. \& Vogt, C. A. (2010). "Identifying the Role of Cognitive, Affective and Behavioural Components in Understanding Residents' Attitudes toward Place Marketing”, Journal of Travel Research, 49(4): 423-445.

MacKay, K. J. \& Couldwell, C. M. (2004). "Using Visitor-Employed Photography to Investigate Destination Image", Journal of Travel Research, 42(4): 390-396.

Malone, S., McCabe, S. \& Smith, A. P. (2014). "The Role of Hedonism in Ethical Tourism", Annals of Tourism Research, 44: 241-254.

Markwell, K. W. (1997). "Dimensions of Photography in a Nature-Based Tour", Annals of Tourism Research, 24(1): 131-155.

Markwell, K. \& Basche, C. (1998). "Using Personal Diaries to Collect Data", Annals of Tourism Research, 25(1): 228-231.

Matteucci, X. (2013). "Photo Elicitation: Exploring Tourist Experiences with Researcher-Found Images", Tourism Management, 35: 190-197.

McKercher, B., Weber, K. \& Du Cros, H. (2008). "Rationalising Inappropriate Behaviour at Contested Sites, Journal of Sustainable Tourism, 16(4): 369-385.

McTaggart, R. (1997). Participatory Action Research: International Contexts and Consequences. Albany: State University of New York.

Miller, G., Rathouse, K., Scarles, C., Holmes, K. \& Tribe, J. (2010). "Public Understanding of Sustainable Tourism", Annals of Tourism Research, 37(3): 627-645.

Phillips, L., Kristiansen, M., Vehviläinen, M. \& Gunnarsson, E. (2013). Knowledge and Power in Collaborative Research: A Reflexive Approach. New York: Routledge.

Prebensen, N. K., Vitters $\emptyset$, J. \& Dahl, T. (2013). "Value Co-Creation Significance of Tourist Resources", Annals of Tourism Research, 42: 240-261.

Pritchard, A., Morgan, N. \& Alteljevic, I. (2011). "Hopeful Tourism: A New Transformative Perspective", Annals of Tourism Research, 38(3): 941-963.

Puczkó, L., Bárd, E. \& Füzi, J. (2010). "Methodological Triangulation: The Study of Visitor Behaviour at the Hungarian Open Air Museum", in G. Richards \& W. Munsters (Eds). Cultural Tourism Research Methods, pp.61-74. Wallingford: CABI.

Reason, P. (1994). "Three Approaches to Participative Inquiry”, in N. K. Denzin \& Y. S. Lincoln (Eds), Handbook of Qualitative Research, pp. 324-339. Thousand Oaks: Sage. Downloaded from: http://www.peterreason.eu/Papers/Three approaches participative inquiry.pdf

Reason, P. (1999). "Integrating Action and Reflection Through Co-operative Inquiry", Management Leaning, 30(2): 207-226.

Richards, V., Pritchard, A. \& Morgan, N. (2010). “(Re)Envisioning Tourism and Visual Impairment”, Annals of Tourism Research, 37(4): 1097-1116. 
Ritchie, J. R. B., Tung, V. W S. \& Ritchie, R. J. B. (2011). “Tourism Experience Management Research: Emergence, Evolution and Future Directions", International Journal of Contemporary Hospitality Management, 23(4): 419-438.

Scarles, C. (2010). "Where Words Fail, Visuals Ignite: Opportunities for Visual Autoethnography in Tourism Research", Annals of Tourism Research, 37(4): 905-926.

Seale, C. (1999). "Quality in Qualitative Research”, Qualitative Inquiry, 5 (4): 465-478.

Sedgley, D., Pritchard, A. \& Morgan, N. (2011). "Tourism and Ageing: A Transformative Research Agenda", Annals of Tourism Research, 38(2): 422-436.

Sharpley, R. (2013). "Responsible Tourism: Whose Responsibility?", in A. Holden and D. Fennell (Eds). The Routledge Handbook of Tourism and the Environment, pp.382-391. Oxon: Routledge.

Shoval, N. \& Isaacson, M. (2010). Tourist Mobility and Advanced Tracking Technologies. New York: Routledge.

Silverman, D. (2015). Interpreting Qualitative Data. London: Sage.

Small, J. (2016) "Holiday Bodies: Young Women and their Appearance", Annals of Tourism Research, 58: 18-32.

Smith, S. L. J. (2010). Practical Tourism Research. Wallingford: CABI.

Sohng, S. S. L. (2005). "Participatory Research Approaches: Some Key Concepts", in J. Gonsalves, T. Becker, A. Braun, D. Campilan, H. De Chavez, E. Fajber, M. Kapiriri, J. Rivaca-Caminade and R. Vernooy (Eds). Participatory Research and Development for Sustainable Agriculture and Natural Resource Management (Volume 1), pp.75-78. Ottawa: International Development Research Centre.

Stanford, D. (2008). "'Exceptional Visitors': Dimensions of Tourist Responsibility in the Context of New Zealand", Journal of Sustainable Tourism, 16(3): 258-275.

Tolkach, D., Pratt, S. \& Zeng, C. Y. H. (2017). "Ethics of Chinese \& Western Tourists in Hong Kong", Annals of Tourism Research, 63: 83-96.

Torbert, W. R. (2001). "The Practice of Action Inquiry", in P. Reason and H. Bradbury (Eds). Handbook of Action Research, pp.207-218. London: Sage.

Tretyak, O. A. \& Sloev, I. (2013). "Customer Flow: Evaluating the Long-Term Impact of Marketing on Value Creation", Journal of Business \& Industrial Marketing, 28(3): 221-228.

Tysbina, E. \& Rebiazina, V. (2013). "Managing Portfolios of Interconnected Customers: Evidence from Russian B2B Market”, Journal of Business \& Industrial Marketing, 28(3): 229-239.

Weeden, C. (2011). "Responsible Tourist Motivation: How Valuable is the Schwartz Value Survey?", Journal of Ecotourism, 10(3): 214-234.

Westwood, S. (2007). "What Lies Beneath? Using Creative, Projective and Participatory Techniques in Qualitative Tourism Research", in I. Ateljevic, A. Pritchard and N. Morgan (Eds). The Critical Turn in Tourism Studies: Innovative Research Methods, pp.293-316. Oxford: Elsevier.

Willson, G. B., McIntosh, A. J. \& Zahra, A. L. (2013). "Tourism and Spirituality: A Phenomenological Analysis", Annals of Tourism Research, 42: 150-168.

World Tourism Organisation (2005). The Responsible Tourist and Traveller. Downloaded from http://ethics.unwto.org/content/responsible-tourist as at 3rd February 2017. 